\title{
Encroachment of woody species on a drained transitional peat bog in 'Mszar Bogdaniec' nature reserve (Western Poland)
}

\author{
Marcin K. Dyderski , Anna K. Gdula1, Andrzej M. Jagodziński ${ }^{2,3} \bowtie$ \\ ${ }^{1}$ Poznań University of Life Sciences, Faculty of Forestry, Wojska Polskiego 28, 60-637 Poznań, Poland \\ ${ }^{2}$ Polish Academy of Sciences, Institute of Dendrology, Parkowa 5, 62-035 Kórnik, Poland, phone: +48-61-8170-033, \\ fax: +48-61-8170-166, e-mail: amj@man.poznan.pl \\ ${ }^{3}$ Poznań University of Life Sciences, Department of Game Management and Forest Protection, Wojska Polskiego 71c, \\ 60-625 Poznań, Poland
}

\section{Abstract}

One of the most important threats for open peat bog ecosystems is encroachment of woody species, which causes transformation of habitat conditions and leads to retreat of specialised species. Drainage increases the rate of succession. The aim of study is the assessment of human-accelerated succession in a transitional bog. The study was conducted in 'Mszar Bogdaniec' nature reserve (W Poland). The structure of vegetation and tree stands was described and compared using ordination methods. Near the peat bog border, tree stands of Betula pubescens developed. Towards the middle part of the peat bog, the number, cover and height of trees decreased. The central part of the peat bog was covered by Sphagno recurvi-Eriophoretum vaginati in dryer parts and Sphagno recurviEriophoretum angustifolii in wetter parts. The study showed that the successional sequence in these conditions differs from the classical bog succession scheme. Despite high propagule pressure of Pinus sylvestris, the most important woody species was $B$. pubescens, which performed better than other species. Erechtites hieracifolia, an alien invasive herb species, which previously was rarely recorded in bogs, appeared when the bog was dried by drainage. In this study, it reached high frequency and abundance, which shows that it may be a next serious threat to disturbed wetland ecosystems.

\section{KEY WORDS}

Betula pubescens; succession; ordination; Vaccinio uliginosi-Betuletum pubescentis; Erechtites hieracifolia

\section{INTRODUCTION}

Although, peat bogs occupy only a small portion of the Earth, they are a very important element of the biosphere. Due to their carbon accumulation abilities, peat bogs - only 3\% of Earth's land surface - contain $550 \mathrm{Gt}$ of carbon, which is equal to the whole terrestrial plant biomass of the world and twice the carbon content in forest biomass worldwide (Parish et al. 2008). Due to water retention functions, peat bogs mitigate floods in 
the catchments and maintain high groundwater table levels (Council National Research 1995; Ilnicki 2002). Specific conditions in peat bogs create unique habitats for a precious species of organisms, some of which are endangered at regional or global scales (Ellenberg 1988; Council National Research 1995; Ilnicki 2002; Żurek 2006; Parish et al. 2008; Schumann and Joosten 2008). As a result of their narrow ecological niches, plant cover is the peat bog ecosystem's element most sensitive to environmental changes (Ellenberg 1988; Schumann and Joosten 2008).

Succession of woody plants in peat bogs is a very important element of vegetation development and determines shifts of plant formation. Its rate, which is low during primary succession in intact peat bogs (Ellenberg 1988; Faliński 1988; Ilnicki 2002; Joosten and Clarke 2002; Parish et al. 2008), depends on hydrological regime (Ellenberg 1988; Herbich and Herbichowa 2002; Joosten and Clarke 2002; Herbichowa et al. 2007). As trees grow larger, they transpire increasing amount of water, contributing to further lowering the groundwater table, which supplies the peat bog (Parish et al. 2008; Fay and Lavoie 2009; Talbot et al. 2010). Moreover, by shading, trees modify light conditions, which significantly influence the floristic composition of understory - the species with high light requirements decrease and are replaced by species with wider ecological tolerances (Kollmann and Rasmussen 2012). Catotelm penetration by root systems of trees also allows oxygen to enter, thus increasing the rate of peat mineralisation in the deeper layers of the peat bog (Herbichowa et al. 2007).

Woody species encroachment into peat bogs is often the result of hydrological changes, due to human activity connected with land use transformation, as well as peat mining. In these cases, the limiting factor - high groundwater table level - is reduced, which results in rapid emergence of dense undergrowth layers and increased growth increments of trees (Macdonald and Yin 1999; Kujawa-Pawlaczyk and Pawlaczyk 2005; Herbichowa et al. 2007; Woziwoda and Kopeć 2014). Sarkkola et al. (2010) found that in drained peat bogs, transpiration by tree stands was the main component of water balance and groundwater table level depended on tree stand volume. The higher the tree stand volume, the lower the groundwater table level due to higher transpiration rate. Fay and Lavoie (2009) proved that spontaneous encroachment by birches (Betula spp.), seriously influenced hydrological relationships of drained peat bogs, by increasing the water deficit as a result of transpiration. Species from the genus Betula have transpiration rates two to three times higher than other deciduous species, for example, Quercus spp. or Fagus spp. Comparing with conifers (e.g. Pseudotsuga spp., Pinus spp., Picea spp.), these differences may be even sevenfold (Kozlowski and Pallardy 1997). Among Polish tree species, only Populus spp. have daily amounts of transpired water higher than Betula spp. (Szaniawski 1979).

So far, most of the published papers concerning the encroachment of trees and shrubs into peat bogs were focussed on phytocoenotic aspects. For example, in NE Denmark, vegetation changes of degraded peat bog have been observed since 1844 and the share of species with high water and light requirements (typical to wetland ecosystems) decreased while the number of woody species increased (Kollmann and Rasmussen 2012). Similar phenomena were observed in other transformed peat bogs (Jasnowski 1962; Herbich 2001; Herbich and Herbichowa 2002; Herbichowa et al. 2007; Haapalehto et al. 2010). However, in intact peat bogs in Sweden, Gunnarsson et al. (2002) also found encroachment of woody species, but they did not find negative impacts on the studied ecosystem. Moreover, they claimed that the appearance of woody species increased the heterogeneity of spatial structure and species composition of the peat bog. They also found higher plant species richness in plots where trees were recorded, caused by creation of new microhabitats suitable, e.g. for shade-tolerant species. However, they did not supply any information about density and diameters of these trees.

Data coming from phytosociological relevés do not provide full information about plant community structure and its transformations. For this reason, assessment of the progress of tree stand development is difficult. Only a few papers have supplied data about basic tree stand parameters (i.e. basal area and tree stand density) along the successional gradient. Czerepko (2010) studied changes in tree stand structure of raised bogs after 35 years. Sarkkola et al. (2003, 2004) studied changes of structures of Scots pine (Pinus sylvestris) tree stands growing on drained raised bogs in Finland. There is a lack of papers merging data about tree stand structures with species composition of plant communities. Only Laine et al. (1995) used tree stand volume as an 
environmental factor in direct gradient analysis of understory vegetation. Most understory species typical for ombrotrophic bogs were negatively correlated with total stand volume and Betula volume.

The aim of this study is (1) to assess the direction of the human-accelerated secondary succession in a raised/transitional bog and (2) to compare two research approaches for identifying vegetation changes of peat bogs: classical phytosociological method and dendroecological approach, considered as a joint phytosociological relevés and biometrical measurements of tree stand parameters.

\section{MAterial AND METHODS}

\section{Study area}

The study was conducted in the 'Mszar Bogdaniec' nature reserve. This place was chosen due to known human impact history and available study of plant cover and soils (Maciantowicz et al. 1999). The 'Mszar Bogdaniec' nature reserve is located in West Poland $\left(51^{\circ} 40^{\prime} 35^{\prime \prime} \mathrm{N} ; 1^{\circ} 21^{\prime} 19^{\prime \prime} \mathrm{E}\right)$ and covers an area of 21.98 ha, including 4.95 ha of peat bog (Zarządzenie 1995;
Maciantowicz et al. 1999). The reserve was established in 1995 for conservation of the raised/transitional bog and breeding sites of wetland birds (Zarządzenie 1995). The bog is located in local low ground without outflow, on impervious substrate. This area was drained in the beginning of the $20^{\text {th }}$ century by the owners by preparing a ditch around the peat bog and two discharge ditches across the bog. In the second half of the $20^{\text {th }}$ century, in the SE part of the bog, ridges were prepared and Scots pine was planted (Maciantowicz et al. 1999). The forests surrounding the bog are secondary forest plant communities with Scots pine and invasive black cherry (Padus serotina) and with Scots pine and Norway spruce (Picea abies).

\section{Methods}

Phytosociological inventory

In September 2012 and 2013, 29 phytosociological relevés were conducted in the most frequent vegetation types occurring in the study area (Figure 1). The relevés were conducted using standard Braun-Blanquet method in homogenous plots with an area depending on the level of community organisation from 2 to $100 \mathrm{~m}^{2}$. Their localities were chosen subjectively in the

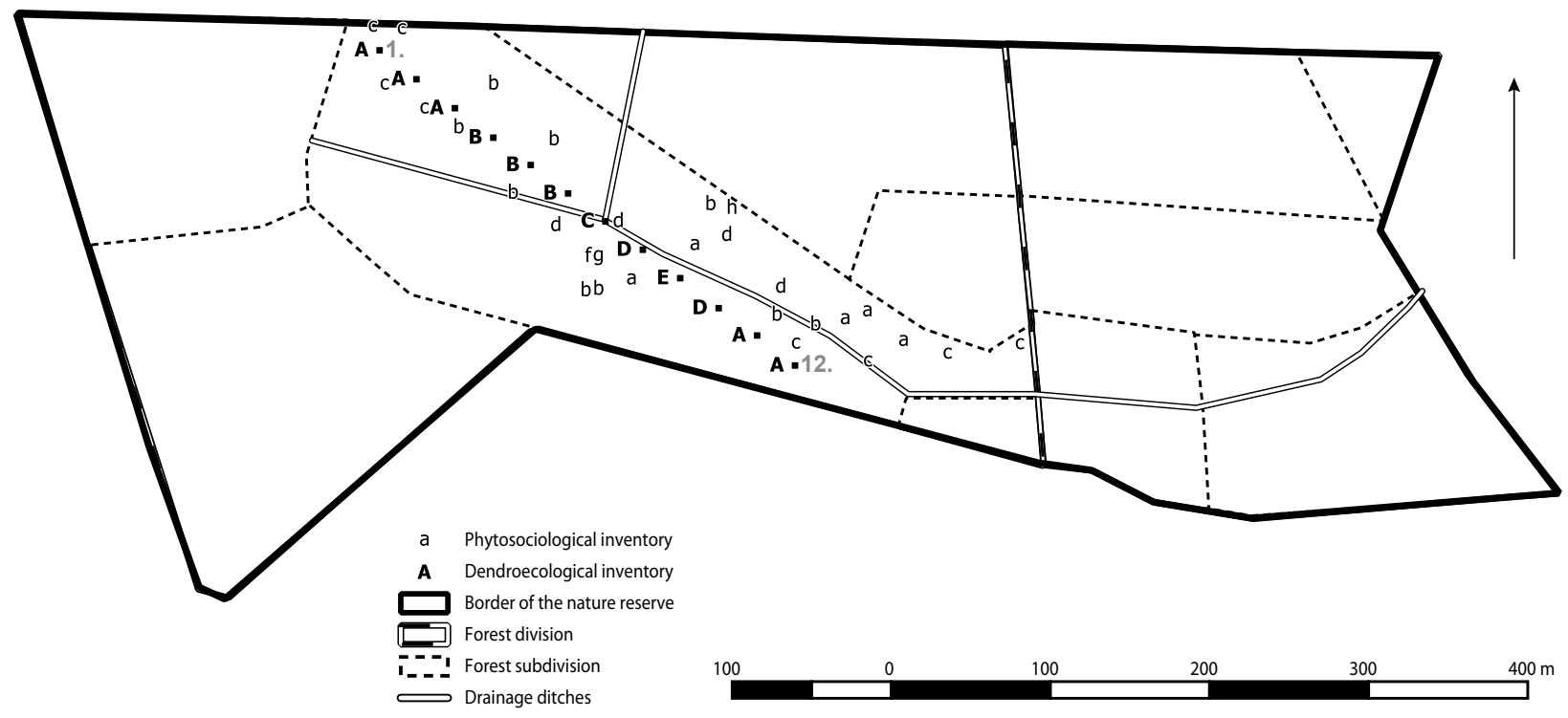

Figure 1. Distribution of the phytosociological relevés and study plots in 'Mszar Bogdaniec'

Numbers '1.' and '12.' indicates the first and last plots in the transect. Small letters - plant communities determined in phytosociological inventory: a - Sphagno recurvi-Eriophoretum angustifolii, b - Sphagno recurvi-Eriophoretum vaginati, c - Vaccinio uliginosi-Betuletum pubescentis, $\mathrm{d}$-Sphagno-Juncetum effusi, $\mathrm{f}$-Scirpetum lacustris, $\mathrm{g}$ - Phragmitetum australis, $\mathrm{h}$ - Ranunculo-Juncetum bulbosi; capital letters - plant communities determined in dendroecological inventory: A - Vaccinio uliginosi-Betuletum pubescentis, B - Sphagno recurvi-Eriophoretum vaginati, C - Scirpetum lacustris, D - Sphagno recurvi-Eriophoretum angustifolii, E - Sphagno-Juncetum effusi. 
most frequent and representative for the studied area vegetation types after field recognition. Plant communities present on relevés were determined based on the criteria of Ratyńska et al. (2011). Relevés from this inventory were deposited in the Polish Vegetation Database (Kącki and Śliwiński 2012).

\section{Dendroecological inventory}

In September 2013, a transect was established along the longest chord of the bog. Square $(10 \times 10 \mathrm{~m})$ experimental plots were established every $30 \mathrm{~m}$ along the transect. In total, 12 plots were established (Figure 1). Therefore, location of plots was systematic and independent of human preferences. In each plot, diameter at breast height $(1.3 \mathrm{~m}$; DBH) was measured for all trees and shrubs with DBH higher than $5 \mathrm{~cm}$. All trees with height above $1.3 \mathrm{~m}$ and with DBH lower than $5 \mathrm{~cm}$ were counted to measure the tree stand density. In each plot, a $25 \mathrm{~m}^{2}$ subplot was randomly selected to measure the natural regeneration and conduct a phytosociological relevé of understory. Natural regeneration was counted in four height-age classes: plants younger than 1 year, 1-year-old plants, 2 years and older plants lower than 0.5 $\mathrm{m}$ and older plants with height between 0.5 and $1.3 \mathrm{~m}$. Phytosociological relevé was conducted only for understory layer (herbaceous and moss layer) and opposite to phytosociological inventory, their locality was independent. Thus, plant community homogeneity criterion had not been taken into account. However, in all plots, understory plant community was homogenous. Plant communities were determined based on the criteria of Ratyńska et al. (2011).

\section{Data analysis}

For results of each inventory, detrended correspondence analysis (DCA) was conducted. For both inventories, cover of vegetation layers, Ellenberg's ecological indicators (Ellenberg and Leuschner 2010) and species richness were fitted as passive variables using permutation tests (999 iterations) to test correlation coefficient $\left(R^{2}\right)$ and statistical significance. Statistically significant $(p<0.05)$ environmental variables were plotted on the DCA graphs. In addition, for results of the dendroecological inventory, basal area and density of the tree stand were also fitted. All analyses were performed in R software (R Core Team, 2013), using the vegan library (Oksanen et al. 2013).

\section{Results}

Different plant communities in the study area were recorded independently of the type of inventory (whether phytosociological or dendroecological). Areas around the border of the peat bog were covered by stands of Betula pubescens trees with admixture of B. pendula and Frangula alnus. The number, cover and height of trees decreased towards the middle of the bog. The central part of peat bog was covered by Sphagno recurviEriophoretum vaginati in drier parts and Sphagno recurvi-Eriophoretum angustifolii in wetter parts.

\section{Phytosociological inventory}

Seven plant associations were recorded (names of associations in bold) in the peat bog:

Class: Vaccinio-Piceetea Br.-Bl. in Br.-Bl. et al. 1939

Order: Piceetalia excelsae Pawłowski in Pawłowski et al. 1928 em. Br.-Bl. in Br.-Bl. et al. 1939

Alliance: Dicrano-Pinion (Libbert 1933) W. Mat. 1962

Vaccinio uliginosi-Betuletum pubescentis Libbert 1933 em. R. Tx. 1937

Class: Isoëto-Litorelletea Br.-Bl. et Vlieger in Vlieger 1937

Order: Litorelletalia uniflorae W. Koch 1926

Alliance: Hydrocotylo-Baldellion R. Tx. et Dierßes in Dierßes 1972

Ranunculo-Juncetum bulbosi Oberd. 1957

Class: Phragmitetea australis (Klika in Klika et Nowák 1941) R. Tx. et Preising 1942

Order: Phragmitetalia australis W. Koch 1926

Alliance: Phragmition communis W. Koch 1926

Phragmitetum communis Kaiser 1926

Scirpetum lacustris (Allorge 1922) Chouard 1924

Class: Scheuchzerio-Caricetea fuscae (Nordhagen 1936) R. Tx. 1937

Order: Caricetalia fuscae Koch 1926 em. Nordhagen 1936

Alliance: Caricion fuscae Koch 1926 em. Klika 1936

Sphagno-Juncetum effusi Dziubaltowski 1928 nom. invers. propos.

Order: Scheuchzerietalia palustris Nordhagen 1936

Alliance: Rhynchosporion albae W. Koch 1926

Sphagno recurvi-Eriophoretum angustifolii Hueck 1925 nom. invers. et nom. mut. 
Class: Oxycocco-Sphagnetea Br.-Bl. et R. Tx. 1943

Order: Sphagnetalia magellanici (Pawłowski in Pawłowski et al. 1928) Kästneret Floßner 1933

Alliance: Sphagnion magellanici Kästner et Floßner 1933

\section{Sphagno recurvi-Eriophoretum vaginati Hueck 1925 nom. invers.}

In the 29 relevés, 37 species of plants (including woody species) were recorded. DCA analysis showed the diversity and relationships among plant communities studied (Figure 2, Table 1). On the left side of ordination space there are points representing Vaccinio uliginosi-Betuletum pubescentis and Sphagno recurviEriophoretum vaginati. These associations are distinguished by high shrub cover, which is correlated with the position of these plant associations in the ordination space. Points representing associations that occurred in the wetter parts of the bog (Sphagno recurvi-Eriophoretum angustifolii and Sphagno-Juncetum effusi) are located in right side of the ordination space. Nearby are two associations of reeds: Scirpetum lacustris and Phragmitetum communis, which were recorded in the discharge ditches. The point representing RanunculoJuncetum bulbosi was the most isolated from other associations. Mean values of Ellenberg's fertility indicator increases from wetter to drier plant communities. Mean Ellenberg's light indicator is strongly correlated with DCA1 axis, differentiating plant associations into variants with differing proportions of species with higher light requirements. The vector representing species richness was correlated with vector representing shrub cover.

The most extensive plant communities represented initial stages of bog birch forest - Vaccinio uliginosiBetuletum pubescentis. These communities occurred in the relatively dry external part of the bog. The tree stands were dominated by $B$. pubescens with an admixture of B. pendula, F. alnus, and rarely - P. sylvestris. In the understory, the most frequent species were Molinia caerulea, Vaccinium myrtillus and natural regeneration of species occurring in the tree layer. In the moss layer, the most frequent species were Sphagnum fimbriatum and Pohlia nutans. Further from the bog's border, the most frequent association was Sphagno recurvi-Eriophoretum vaginati. In this association, E. vaginatum dominated the community structure. Between the clumps of E. vaginatum there were frequent and abundant natural regeneration of birches, Scots pine and $F$. alnus. Frequent accompanying species were $E$. angustifolium and invasive Erechtites hieracifolia. In the wetter, central part of peat bog, there were two associations from the Scheuchzerio-Caricetea class: Sphagno recurvi-Eriophoretum angustifolii and SphagnoJuncetum effusi. In the former, E. angustifolium dominated the community structure, with an admixture of Hydrocotyle vulgaris, less abundant E. vaginatum

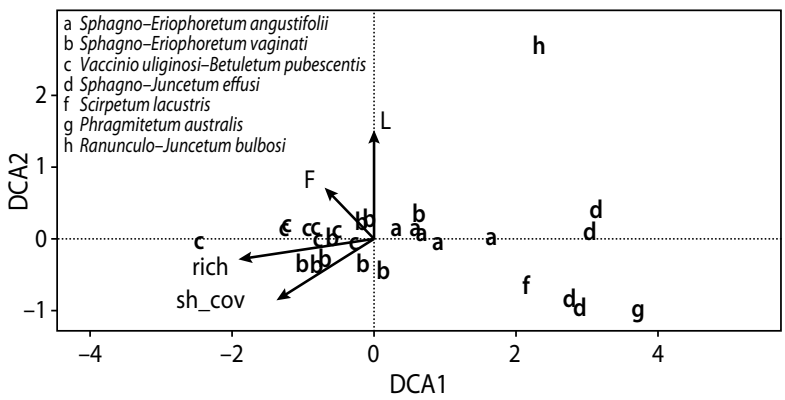

Figure 2. The result of DCA analysis of 29 relevés from the phytosociological inventory. Analysis parameters: eigenvalues for DCA1 0.7034, for DCA2 0.2700; axis length: DCA1 6.1694, DCA2 3.7411. Abbreviations of environmental factors are explained in Table 1. DCA: detrended correspondence analysis

Table 1. Parameters of environmental variables fitted to DCA analysis conducted on relevés from the phytosociological inventory. DCA: detrended correspondence analysis

\begin{tabular}{|c|c|c|c|c|c|}
\hline \multicolumn{2}{|c|}{ Parameter } & DCA1 & DCA2 & $\mathrm{r}^{2}$ & $\operatorname{Pr}(>\mathrm{r})$ \\
\hline $\begin{array}{l}\text { Species } \\
\text { richness }\end{array}$ & rich & -0.98847 & -0.15140 & 0.6034 & $<0.001^{* * *}$ \\
\hline \multicolumn{6}{|c|}{ Cover of } \\
\hline trees & tr_cov & -0.98709 & -0.16016 & 0.1947 & 0.117 \\
\hline shrubs & sh_cov & -0.84614 & -0.53296 & 0.4270 & $<0.001^{* * *}$ \\
\hline herbs & he_cov & 0.68126 & 0.73204 & 0.0634 & 0.346 \\
\hline mosses & mo_cov & -0.50606 & -0.86250 & 0.1810 & 0.055 \\
\hline \multicolumn{6}{|c|}{ Ellenberg's ecological indicators of } \\
\hline fertility & $\mathrm{F}$ & -0.69943 & 0.71470 & 0.1644 & $0.045^{*}$ \\
\hline moisture & M & 0.09952 & 0.99504 & 0.0823 & 0.254 \\
\hline light & $\mathrm{L}$ & 0.00294 & 1 & 0.3789 & $0.003^{* *}$ \\
\hline soil reaction & SR & -0.30445 & 0.95253 & 0.0755 & 0.253 \\
\hline
\end{tabular}

Correlation $\mathrm{r}^{2}$ coefficient and significance level $(* \mathrm{p}<0.05 ; * * \mathrm{p}<0.01$; $* * * \mathrm{p}<0.001)$ were computed by permutation test (999 iterations). DCA: detrended correspondence analysis. 
(transitioning from the neighbouring Sphagno recurviEriophoretum vaginati) and E. hieracifolia. In the latter, Juncus effusus was dominant, with an admixture of species from Scheuchzerio-Caricetea class: H. vulgaris and Carex canescens. In the stagnant water where the two discharge ditches cross, two reed associations occurred: Phragmitetum communis and Scirpetum lacustris, monoculture aggregations of Phragmites australis and Scirpus lacustris, respectively. At the shore of astatic pond, Ranunculo-Juncetum bulbosi was found, dominated by J. bulbosus.

\section{Dendroecological inventory}

Five plant associations were found: Vaccinio uliginosi-Betuletum pubescentis (5 plots), Scirpetum lacustris (1 plot), Sphagno-Juncetum effusi (1 plot), Sphagno recurvi-Eriophoretum angustifolii (2 plots) and Sphagno recurvi-Eriophoretum vaginati (3 plots). On the 12 plots, 24 plant species were recorded. Woody species were present on 10 of the 12 plots, including one on which only dead trees were recorded (B. pendula and $P$. sylvestris). Trees and shrubs were lacking in the shrub layer (over $50 \mathrm{~cm}$ of height) in Scirpetum lacustris, Sphagno-Juncetum effusi and one of two plots with Sphagno recurvi-Eriophoretum angustifolii. On the other plots ( 9 of 12), a shrub and tree layers were in 5 of 12 plots. The highest density of trees and greatest basal area was on plots with Vaccinio uliginosi-Betuletum pubescentis (2,100 to 10,100 ind. ha ${ }^{-1}$ and 0.6554 to $9.7145 \mathrm{~m}^{2} \mathrm{ha}^{-1}$, respectively).

The highest densities of natural regeneration were of B. pubescens (present in 9 of 12 plots, 400-534,400 ind. $\mathrm{ha}^{-1}$ ) (Table 2). Natural regeneration of $F$. alnus occurred in 7 of 12 plots (2800-152,000 ind. ha- $\left.{ }^{-1}\right)$, and the natural regeneration of $P$. sylvestris was found only in 4 of 12 plots ( $800-8000$ ind. ha-1). The highest densities of natural regeneration of all species were on plots with Vaccinio uliginosi-Betuletum pubescentis.

Table 2. Densities of natural regeneration recorded on experimental plots in the dendroecological inventory. All values in table are ind. ha ${ }^{-1}$

\begin{tabular}{|c|c|c|c|c|c|c|c|c|c|c|c|c|c|}
\hline \multirow{4}{*}{$\begin{array}{l}\text { Species } \\
\text { name }\end{array}$} & \multirow{4}{*}{$\begin{array}{l}\text { Height- } \\
\text { age } \\
\text { class }^{1}\end{array}$} & \multicolumn{12}{|c|}{ Successive number of plot } \\
\hline & & 1 & 2 & 3 & 4 & 5 & 6 & 7 & 8 & 9 & 10 & 11 & 12 \\
\hline & & \multicolumn{12}{|c|}{ Plant association $^{2}$} \\
\hline & & 1 & 1 & 1 & 2 & 2 & 2 & 3 & 4 & 5 & 4 & 1 & 1 \\
\hline \multirow{5}{*}{$\begin{array}{l}\text { Betula } \\
\text { pubescens }\end{array}$} & Class 1 & 76,400 & 447,200 & 2,800 & 400 & 400 & 400 & 0 & 0 & 0 & 0 & 0 & 4,800 \\
\hline & Class 2 & 25,200 & 69,200 & 6,800 & 1,600 & 0 & 400 & 0 & 0 & 0 & 400 & 1,200 & 0 \\
\hline & Class 3 & 28,800 & 17,200 & 7,600 & 1,600 & 1,200 & 0 & 0 & 0 & 0 & 0 & 0 & 400 \\
\hline & Class 4 & 0 & 800 & 400 & 0 & 0 & 0 & 0 & 0 & 0 & 0 & 0 & 0 \\
\hline & Total & 130,400 & 534,400 & 17,600 & 3,600 & 1,600 & 800 & 0 & 0 & 0 & 400 & 1,200 & 5,200 \\
\hline \multirow{5}{*}{$\begin{array}{l}\text { Frangula } \\
\text { alnus }\end{array}$} & Class 1 & 11,200 & 89,200 & 8,000 & 1,600 & 2,400 & 0 & 0 & 0 & 0 & 0 & 0 & 1,200 \\
\hline & Class 2 & 6,400 & 38,800 & 400 & 1,600 & 2,000 & 400 & 0 & 0 & 0 & 0 & 0 & 0 \\
\hline & Class 3 & 7,200 & 22,400 & 5,600 & 3,200 & 6,000 & 800 & 0 & 0 & 0 & 0 & 0 & 800 \\
\hline & Class 4 & 0 & 1,600 & 4,400 & 2,000 & 800 & 1,600 & 0 & 0 & 0 & 0 & 0 & 800 \\
\hline & Total & 24,800 & 152,000 & 18,400 & 8,400 & 11,200 & 2,800 & 0 & 0 & 0 & 0 & 0 & 2,800 \\
\hline \multirow{5}{*}{$\begin{array}{l}\text { Pinus } \\
\text { sylvestris }\end{array}$} & Class 1 & 1,200 & 6,000 & 0 & 0 & 0 & 0 & 0 & 0 & 0 & 0 & 0 & 400 \\
\hline & Class 2 & 0 & 2,000 & 0 & 0 & 0 & 0 & 0 & 0 & 0 & 0 & 0 & 400 \\
\hline & Class 3 & 0 & 0 & 0 & 0 & 0 & 0 & 0 & 0 & 0 & 0 & 1,200 & 0 \\
\hline & Class 4 & 0 & 0 & 0 & 0 & 0 & 0 & 0 & 0 & 0 & 0 & 400 & 0 \\
\hline & Total & 1,200 & 8,000 & 0 & 0 & 0 & 0 & 0 & 0 & 0 & 0 & 1,600 & 800 \\
\hline
\end{tabular}

Explanations: 1 - height-age classes: class 1: seedlings younger than 1 year, class 2: 1-year-old trees; class 3: tress older than 1 year with height lower than $50 \mathrm{~cm}$; class 4: trees older than 1 year with height between 50 and $130 \mathrm{~cm} ; 2$ - Plant association: 1 - Vaccinio uliginosi-Betuletum pubescentis; 2 - Sphagno recurvi-Eriophoretum vaginati; 3 - Scirpetum lacustris; 4 - Sphagno recurvi-Eriophoretum angustifolii; 5 - Sphagno-Juncetum effusi. 
The natural regeneration of $P$. sylvestris was recorded mainly in the first two classes with trees younger than 2 years. The older trees, up to $50 \mathrm{~cm}$ (1200 ind. ha $\left.{ }^{-1}\right)$ and between 50 and $130 \mathrm{~cm}$ height (400 ind. ha- ${ }^{-1}$ ) were recorded only on one plot. Natural regeneration of B. pubescens was more abundant near the NW border of the peat bog than near the SE border. Density of natural regeneration was highest in the NW part of the bog on the first two plots with the highest tree densities. First class (seedlings, $<1$-year-old trees) reached 76,400 and 447,200 ind. ha ${ }^{-1}$, second class (1-year-old trees) reached 25,200 and 69,200 ind. ha ${ }^{-1}$ and third class (older, up to $50 \mathrm{~cm}$ height) reached 28,800 and 17,200 ind. ha $^{-1}$. Fourth class was present only on plot no. 2 (800 ind. ha-1). On plot no. 3, all classes of B. pubescens natural regeneration were present, but the density of $2^{\text {nd }}$ and $3^{\text {rd }}$ classes were higher than first and fourth. On plots of Vaccinio uliginosi-Betuletum pubescentis from the SE part of the bog (plots no. 11 and 12), densities were lower - from 0 to maximally 4800 ind. ha ${ }^{-1}$, and the fourth class was not recorded. On plots with Sphagno recurvi-Eriophoretum vaginati, the densities of $B$. pubescens natural regeneration were lower: from 400 to 1600 ind. ha $^{-1}$ in each class, but the fourth class (older than 2 years and higher than $50 \mathrm{~cm}$ ) was not recorded. Natural regeneration of $F$. alnus had similar densities: the highest values in Vaccinio uliginosi-Betuletum pubescentis, the lowest in Sphagno recurvi-Eriophoretum vaginati, and no natural regeneration in other plant associations.

DCA conducted for relevés from the dendroecological inventory showed grouping of the relevés along DCA1 axis (Figure 3, Table 3). On the left side of the ordination space, there are points representing two plant associations: Vaccinio uliginosi-Betuletum pubescentis and Sphagno recurvi-Eriophoretum vagina$t i$, which are correlated with higher tree stand density and basal area. Points representing associations typical for transitional bogs from Scheuchzerio-Caricetea (Sphagno-Juncetum effusi and Sphagno recurvi-Eriophoretum angustifolii) are located in the right side of the ordination space. Furthest right was a point representing the reed community - Scirpetum lacustris. The vector representing the shrub layer cover is correlated with tree stand parameters (density and basal area) as well as species richness. All these parameters reached the highest values in Vaccinio uliginosi-Betu- letum pubescentis. The Ellenberg's light indicator is negatively correlated with these parameters.

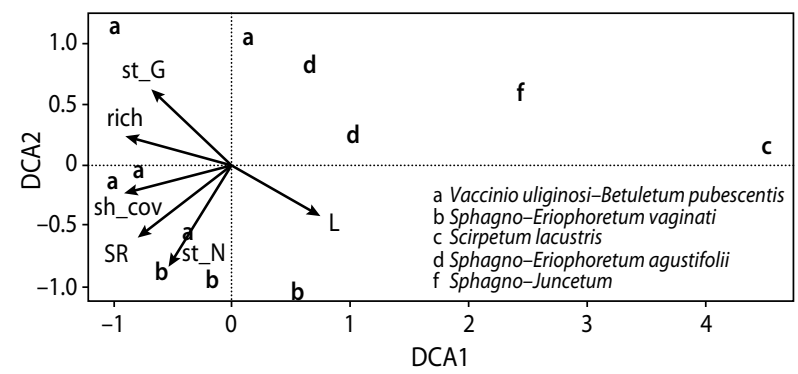

Figure 3. The result of DCA analysis of 12 relevés from the dendroecological inventory. Analysis parameters: eigenvalues for DCA1 0.6394, for DCA2 0.3643; axis length: DCA1 5.5163, DCA2 2.1719. Abbreviations of environmental factors are explained in Table 3. DCA: detrended correspondence analysis

Table 3. Parameters of environmental variables fitted to DCA analysis conducted on relevés from dendroecological inventory. DCA: detrended correspondence analysis

\begin{tabular}{|c|c|c|c|c|c|}
\hline \multicolumn{2}{|c|}{ Parameter } & DCA1 & DCA2 & $r^{2}$ & $\operatorname{Pr}(>\mathrm{r})$ \\
\hline $\begin{array}{l}\text { Species } \\
\text { richness }\end{array}$ & rich & -0.96635 & 0.25723 & 0.6671 & $0.012^{*}$ \\
\hline \multicolumn{6}{|c|}{ Cover of } \\
\hline trees & tr_cov & -0.97046 & -0.24128 & 0.1967 & 0.401 \\
\hline shrubs & sh_cov & -0.96860 & -0.24861 & 0.6757 & $0.013^{*}$ \\
\hline herbs & he_cov & 0.33142 & -0.94348 & 0.0217 & 0.924 \\
\hline mosses & mo_cov & -0.93797 & -0.34671 & 0.4315 & 0.116 \\
\hline \multicolumn{6}{|c|}{ Ellenberg's ecological indicators of } \\
\hline fertility & $\mathrm{F}$ & -0.99382 & -0.11101 & 0.1529 & 0.519 \\
\hline moisture & M & 0.98584 & 0.16767 & 0.2161 & 0.391 \\
\hline light & $\mathrm{L}$ & 0.86832 & -0.49600 & 0.5600 & $0.047^{*}$ \\
\hline $\begin{array}{l}\text { soil } \\
\text { reaction }\end{array}$ & SR & -0.80036 & -0.59952 & 0.7647 & $0.010^{* *}$ \\
\hline \multicolumn{6}{|c|}{ Tree stand parameters } \\
\hline $\begin{array}{l}\text { basal area } \\
{\left[\mathrm{m}^{2} \mathrm{ha}^{-1}\right]}\end{array}$ & st_G & -0.74114 & 0.67135 & 0.5578 & $0.009^{* *}$ \\
\hline $\begin{array}{l}\text { density } \\
{\left[\text { ind. } \text { ha }^{-1}\right]}\end{array}$ & st_N & -0.54253 & -0.84004 & 0.6489 & $0.012^{*}$ \\
\hline
\end{tabular}

Correlation $\mathrm{r}^{2}$ coefficient and significance level $(* \mathrm{p}<0.05 ; * * \mathrm{p}<0.01$; $* * * \mathrm{p}<0.001$ ) were computed by permutation test (999 iterations).

DCA: detrended correspondence analysis.

In the external part of the bog, there were Vaccinio uliginosi-Betuletum pubescentis, young tree stands with $B$. pubescens, B. pendula and $F$. alnus. This last species had twice the density of $B$. pubescens in the 
NW part of the bog and was absent in SE part of the bog, where $P$. sylvestris occurred as a result of former forest management (in plot no. 12). The most abundant understory species were M. caerulea, E. vaginatum and E. hieracifolia together with natural regeneration of trees and shrubs. In the moss layer, the most frequent and abundant species were $S$. cuspidatum, S. fimbriatum and $P$. nutans. Further from bog's border occurred Sphagno recurvi-Eriophoretum vaginati, dominated by clumps of $E$. vaginatum, with accompanying E. hieracifolia. The wetter part of peat bog (near the discharge ditches) was occupied by Sphagno-Juncetum effusi and Sphagno recurvi-Eriophoretum angustifolii, the moss layer was poorly developed and herbaceous layer species from Scheuchzerio-Caricetea dominated: E. angustifolium, J. effusus and H. vulgaris. These species were also accompanied by E. hieracifolia. Natural regeneration of trees and shrubs were not abundant. In the cross of the discharge ditches (plot no. 7; Figure 1), a reed community - Scirpetum lacustris occurred.

\section{Comparison of results from both inventories}

The dendroecological inventory recorded 24 species in 12 relevés, while the phytosociological inventory recorded 37 species in 29 relevés. In total, 22 species were common to both inventories. Species composition of recorded plant communities was similar, independently on sampling protocol - whether plots were chosen subjectively or systematically. The points representing the same plant communities in DCA analyses for both inventories were similarly located: on the left side of the ordination space were Vaccinio uliginosi-Betuletum pubescentis and Sphagno recurvi-Eriophoretum vaginati and other plant associations were on the right side. Tree stand parameters (density and basal area) measured during dendroecological inventory were correlated with DCA results explaining 56 and $65 \%$ of species composition variability of studied plant communities in DCA ordination space.

\section{Discussion}

A successional gradient from open peat bog communities to relatively dry forest associations was observed in the study area for both inventory methods. In the driest part of the bog (near borders), tree stand pa- rameters (density and basal area) as well as density of natural regeneration of trees and shrubs were highest. The wetter part of the peat bog had lower tree stand parameters (basal area and density) and natural regeneration densities.

\section{Encroachment of the trees and shrubs on peat bog}

In the peat bog, the first woody species to enter were $B$. pubesens and $F$. alnus, however, the latter species gave way to $B$. pubescens. Scots pine appeared only in SE part of the bog, however, its presence was an effect of former planting (Maciantowicz et al. 1999). The survival of Scots pine seedlings in all experimental plots was low. Most likely, this was an effect of lower competition abilities of Scots pine in conditions of drained transitional bog with expansion of herbaceous plants (e.g. M. caerulea, E. vaginatum) as well as woody species with higher rates of height increment (B. pubescens, $F$. alnus). These conditions cause lower light availability, due to high density and cover of shrub and herbaceous layers.

Freléchoux et al. (2003), studying mountain bogs in Switzerland, found that communities with B. pubescens compose an intermediate stage of succession between open raised bogs and Norway spruce forests. This intermediate stage is a relatively persistent plant community. It can be assumed that $B$. pubescens is a species facilitating entering late-successional species by habitat modification: shading, decreasing groundwater table level and increasing nutrient availability (Johansson 1995; Kozlowski and Pallardy 1997; Fay and Lavoie 2009). Cohorts of F. alnus and B. pubescens seedlings appear at the same time, however, B. pubescens is able to grow under a canopy (Zarzycki 1979; Czerepko 2010) and $F$. alnus facilitates the survival of $B$. pubescens in the first year. Due to the different rates of height increment, after several years, B. pubescens overgrows $F$. alnus and dominates the young forest canopy in the initial stage of Vaccinio uliginosi-Betuletum pubescentis.

High densities of $B$. pubescens natural regeneration are a result of habitat availability, however, few trees reach heights above $50 \mathrm{~cm}$. Although, lowering the groundwater table and partial peat mineralisation increases habitat availability for trees (Limpens et al. 2003; Herbichowa 2004), seedlings in the inner part of 
the bog most often lose in competition with expansive herbaceous species, that is, M. caerulea and E. vaginatum. M. caerulea is an especially expansive species, which in conditions of lowering groundwater table and increased nitrogen availability, may become a dominant component of vegetation in extensive areas (Limpens et al. 2003; Herbichowa 2004, 2005; Tomassen et al. 2004), which limits the light availability for seedlings of trees and shrubs. At the border of the bog in conditions of more mineralised peat, the presence of tree stands and deeper drainage cause higher survival probability for seedlings. Sarkkola et al. (2004), based on their observations from permanent plots, argued that higher survival probabilities and better conditions for development of seedlings and saplings occur during the first 20 years after drainage.

Presence of dead $B$. pendula and $P$. sylvestris specimens in some of plots may be an effect of temporal groundwater variability connected with various precipitation in previous decades. It may reflect the germination-dying off concept (Eckstein et al. 2011) typical for undisturbed mires. According to this concept, dead trees may be remains of tree stand, which emerged in an optimal hydrological phase (i.e. few years with lower groundwater table level) and after some years, with higher precipitation, these trees died. Information about fluctuations in tree stand cover in 'Mszar Bogdaniec' was also supplied in Maciantowicz et al. (1999). It may show that even in a drained bog, processes determining population dynamics of trees occur in a similar way. However, this assumption needs further research, especially because most of the dead trees were found in the SE part of the bog where ridges were prepared for pine plantation and it could influence hydrological conditions in this part of bog, which may also explain spatial variation in natural B. pubescens regeneration.

\section{Model of succession}

\section{in the drained transitional bog}

The successional gradient, observed by the dendroecological inventory, has shown how the relationship between tree stand parameters and succession progresses. In drained plant communities typical for transitional bog (from class Scheuchzerio-Caricetea: Sphagno-Juncetum effusi and Sphagno recurvi-Eriophoretum angustifolii) or for raised bog (recorded in previous study as Sphagnetum magellanici (Maciantowicz et al. 1999), these plant communities transform into a species-poor association of Sphagno recurviEriophoretum vaginati, which is typical for degraded and drained raised bogs (Jasnowski 1962; Herbichowa 2004; Ratyńska et al. 2011). In this plant association together with further lowering of the groundwater table, the conditions promote establishment of $M$. caerulea, $F$. alnus and $B$. pubescens. In this stage, the growth of $F$. alnus and B. pubescens leads to the formation of a dense shrub layer. The increasing shrub layer cover with decreasing moisture was described for example by Gunnarsson et al. (2002), Fay and Lawoie (2009) and Talbot et al. (2010). The shrub community creates conditions more suitable to higher incremental growth of B. pubescens, which starts to create dense tree stands that can replace $F$. alnus. This is a result of the dynamics of $B$. pubescens height increment in the first year of life and higher maximum height of $B$. pubescens. Massive occurrence of $B$. pubescens causes feedbacks - due to high efficiency of foliage; its transpiration rate is very high (Szaniawski 1979; Kozlowski and Pallardy 1997), which leads to further drainage (Herbichowa et al. 2007; Parish et al. 2008; Fay and Lavoie 2009; Talbot et al. 2010). This positive feedback between shrubs and trees in boreal peat bogs was also described by Holmgren et al. (2015).

This case study is different from the classical scheme of succession in raised bogs. This scheme includes massive entering of Scots pine and a stage of pine bog forest Vaccinio uliginosi-Pinetum, as an important phase of succession (Jasnowski 1962; Ellenberg 1988; Herbich 2001; Herbich and Herbichowa 2002; Herbichowa et al. 2007; Czerepko 2010, 2011). The lack of the Vaccinio uliginosi-Pinetum stage and even plant communities referring to this stage, both in this study as well as in historical materials (Maciantowicz et al. 1999), suggests another course of succession. Although, the size of propagule bank in the nearest neighbourhood is sufficient (bog is surrounded by tree stands of Scots pine), this species' survival is low and it is not numerous. It may suggest that in conditions of strong peat mineralisation and release of nitrogen (Maciantowicz et al. 1999) as well as lowering the groundwater table, species with higher resource requirements (i.e. B. pubescens, $F$. alnus) are better competitors than Scots pine. It also shows that seedlings of $B$. pubescens and $F$. alnus 
are less vulnerable to competition with the herbaceous layer, especially E. vaginatum and M. caerulea, which are stronger competitors than Scots pine seedlings. A similar pathway of succession in raised and transitional bogs found in this study was observed only in Łebskie Bagno and Czarne Bagno (N Poland) by Herbich and Herbichowa (2011).

\section{Differences in floristic composition of understory in successional stages}

In the late-successional stages, the number of species typical to bogs was lower than in early-successional stages. Czerepko (2011) found that the share of species typical for bogs decreased and share of species typical for coniferous forests increased over the past 35 years in bog pine forests (Vaccinio uliginosi-Pinetum) of NE Poland. Based on data from the dendroecological and phytosociological inventories, this study showed differences in floristic composition of the plant associations studied. Although, the species richness increased along a successional gradient, the number of species typical for bogs did not increase. Moreover, in Vaccinio uliginosi-Betuletum pubescentis, the cover of $M$. caerulea was high and in the future, may dominate the floristic composition of the forest decreasing the species richness (due to dominancy and competition). This species is also an indicator of drainage and degradation of this plant association in natural habitats (Jasnowski 1962; Ellenberg 1988; Herbich 2001; Herbich and Herbichowa 2002; Herbichowa 2004).

In addition to native species not typical for bogs entering the plant community, attention should be paid to invasion of E. hieracifolia. This species comes from North America where it is a common and important weed (Darbyshire et al. 2012). Although this species was rarely recorded in wetland ecosystems and Chmura (2004) did not find it in raised bog, Orlov and Yakushenko (2011) and Koczywąs et al. (2012) provided information about some occurrences in bogs. Also, Tokarska-Guzik et al. (2009) and Koczywąs et al. (2012) found the species in reed communities and along streams. In the area studied by us, E. hieracifolia had its ecological optimum in degraded raised/transitional bog plant associations: Sphagno recurvi-Eriophoretum vaginati and Sphagno recurvi-Eriophoretum angustifolii, reaching cover up to $25 \%$ and high frequency. It also appeared in a clearing near the nature reserve in which the study took place and in the neighbouring (c.a. $1 \mathrm{~km}$ ) 'Baszków' nature reserve (Gdula et al. 2014). Its habitat preferences in invaded range include clearings and forest paths in habitats of coniferous and mixed coniferous forests (Chmura 2004; Orlov and Yakushenko 2011; Koczywąs et al. 2012), which are considered to have similar fertility range to plant associations where E. hieracifolia had its optimum in this study (Ratyńska et al. 2011). This may show that E. hieracifolia may be especially problematic to drained transitional bogs and due to its quick expansion and recent manifestation of invasiveness (Chmura 2004; Orlov and Yakushenko 2011; Koczywąs et al. 2012), all localities of this species should be monitored.

\section{Comparison of dendroecological and phytosociological approach}

Compared with classic phytosociological inventories, dendroecological inventories provide important additional data about tree stands, which are correlated with the data on plant communities, although phytosociological relevés provide information about presence and abundance of woody species. Moreover, data about vegetation layers cover may be a base to discuss vegetation changes connected with encroachment of woody species into non-forest habitats. However, dendroecological approach provides more data, which allow to more precise assessment of succession progress and using data about trees increments may be useful to predict the strength of vegetation changes in future. Similarly to Laine et al. (1995), data about tree stands were strongly correlated with the diversity of plant communities. Due to this information, the strength of woody species expansion and progress of succession could be quantified. Based on tree stand data, it will be possible to predict the near-future direction and dynamics of successional processes. Updating data about species composition of plant communities by tree stand parameters will help assessing the progress of succession and projecting management and conservation guidelines.

\section{Conclusions}

In the drained raised/transitional bog in 'Mszar Bogdaniec' nature reserve, we can observe human-altered succession - encroachment of woody species and 
formation of a forest plant community dominated by B. pubescens. This succession goes from communities typical for raised and transitional bogs by its degenerated form typical for drained sites - Sphagno revurvi-Eriophoretum vaginati, to shrubs with $F$. alnus and $B$. pubescens. Due to different dynamics of height increment in the first year of life of these two species, B. pubescens is able to grow under the canopy of $F$. alnus and overtop it over a period of several years. Tree stand parameters (density and basal area) are important variables, which explain species composition of a variety of plant communities. This data may be provided by dendroecological inventory and allows prediction of further successional progress. The successional pathway documented in this study is different from the classic scheme woody species entering drained bogs. It may show that in conditions of transitional bogs, Scots pine is not able to compete with herbaceous and woody competitors and species with higher trophic requirements, so that $B$. pubescens becomes the most important and dominant tree species. Therefore, expansion of $B$. pubescens should be a warning in bog monitoring before more dramatic ecosystem changes. Moreover, the process of succession in drained transitional peat bog created suitable conditions for the expansion of alien invasive herb $-E$. hieracifolia, which previously was rarely recorded in wetland ecosystems. This shows the capability of this species to invade disturbed peat bogs, which, due to recent manifestation of invasiveness, may be the new serious threat to transitional bog vegetation.

\section{Acknowledgements}

We would like to thank Dr. Lee E. Frelich (Department of Forest Resources, University of Minnesota, USA) for linguistic revision of the manuscript. We also thank Mr. Wiesław Buliński, Mr. Bogdan Staniek and Mr. Bogdan Wiatrak from Krotoszyn Forest District for logistic help, sharing the documents and valuable remarks about the area of the study. We are also grateful to Dr. Anna Rusińska (Adam Mickiewicz University, Poznań, Poland) for the verification of mosses determination. We also thank two anonymous Reviewers for valuable comments, which increased the quality of the paper. We declare that the study complies with the current laws of Poland.

\section{References}

Chmura D. 2004. Penetration and naturalisation of invasive alien plant species (neophytes) in woodlands of the Silesian Upland (southern Poland). Nature Conservation, 60, 3-11.

Council National Research. 1995. Wetlands: characteristics and boundaries. National Academy Press, Washington, D.C.

Czerepko J. 2010. Changes in the structure of tree stands on bog habitats in the Białowieża forest. Folia Forestalia Polonica, Series A - Forestry, 52, 33-43.

Czerepko J. 2011. Long-term vegetation change in marshy pine forest Vaccinio uliginosi-Pinetum Kleist 1929. Forest Research Papers, 72, 21-29.

DAISIE European Invasive Alien Species Gateway. 2014. Erechtites hieracifolia. http://www.europealiens.org/speciesFactsheet.do?speciesId=22476; Accessed 14.11.2015.

Darbyshire S.J., Francis A., DiTommaso A., Clements D.R. 2012. The biology of Canadian weeds. 150 Erechtites hieraciifolius (L.) Raf. ex DC. Canadian Journal of Plant Science, 92, 729-746.

Eckstein J., Leuschner H.H., Bauerochse A. 2011. MidHolocene pine woodland phases and mire development - significance of dendroecological data from subfossil trees from northwest Germany. Journal of Vegetation Science, 22, 781-794.

Ellenberg H. 1988. Vegetation ecology of Central Europe. Cambridge University Press, Cambridge.

Ellenberg H., Leuschner C. 2010. Vegetation Mitteleuropas mit den Alpen in ökologischer, dynamischer und historischer Sicht. UTB, Stuttgard.

Faliński J.B. 1988. Succession, regeneration and fluctuation in the Białowieża Forest (NE Poland). Vegetatio, 77, 115-128.

Fay E., Lavoie C. 2009. The impact of birch seedlings on evapotranspiration from a mined peatland: an experimental study in southern Quebec, Canada. Mires and Peat, 5, 1-7.

Freléchoux F., Buttler A., Gillet F., Gobat J.M., Schweingruber F.H. 2003. Succession from bog pine (Pinus uncinata var. rotundata) to Norway spruce (Picea abies) stands in relation to anthropic factors in Les Saignolis bog, Jura Mountains, Switzerland. Annales of Forest Science, 60, 347-356. 
Gdula A.K., Dyderski M.K., Jagodziński A.M. 2014. Habitat preferences of royal fern Osmunda regalis L. in the 'Baszków' nature reserve. Folia Forestalia Polonica, Series A - Forestry, 56 (4), 171-178.

Gunnarsson U., Malmer N., Rydin H. 2002. Dynamics or constancy in Sphagnum dominated mire ecosystems? A 40-year study. Ecography, 25, 685-704.

Haapalehto T.O., Vasander H., Jauhiainen S., Tahvanainen T., Kotiaho J.S. 2010. The effects of peatland restoration on water-table depth, elemental concentrations, and vegetation: 10 years of changes. Restoration Ecology, 19, 587-598.

Herbich J. 2001. Changes in vegetation in the "Staniszewskie Błoto" nature reserve within the last 30 years (in Polish). Prace Geograficzne IGiZP PAN, 179, 85-94.

Herbich J., Herbichowa M. 2002. Peatland vegetation in Poland (in Polish). In: Peatland and peat (ed.: P. Ilnicki), Wydawnictwo Akademii Rolniczej im. Augusta Cieszkowskiego, Poznań, 179-203.

Herbich J., Herbichowa M. 2011. Dynamic tendences of plant communities and changes predictions (in Polish). In: The nature of Łebskie Bagno and Czarne Bagno reserves (eds.: M. Herbichowa, J. Herbich), Fundacja Rozwoju Uniwersytetu Gdańskiego, Gdańsk, 210-215.

Herbichowa M. 2004. Degraded raised bogs still capable of natural regeneration (in Polish). In: Inland water and peatbogs. Guidelines for habitats and species protection within Natura 2000 - methodological handbook. T. 2 (ed.: J. Herbich), Min. Środowiska, Warszawa, 140-146.

Herbichowa M., Pawlaczyk P., Stańko R. 2007. Conservation of Baltic raised bogs in Pomerania, Poland. Experience and Results of the LIFE04NAT/ PL/000208 PLBALTBOGS Project. Wydawnictwo Klubu Przyrodników, Świebodzin.

Holmgren M., Lin C.Y., Murillo J.E., Nieuwenhuis A., Penninkhof J., Sanders N., van Bart T., van Veen H., Vasander H., Vollebregt M.E., Limpens J. 2015. Positive shrub-tree interactions facilitate woody encroachment in boreal peatlands. Journal of Eco$\log y, 103,58-66$.

Ilnicki P. 2002. Peatland and peat (in Polish). Wydawnictwo Akademii Rolniczej im. Augusta Cieszkowskiego, Poznań.
Jasnowski M. 1962. Bauund Vegetation die Moore des Stettiner Pommerans (in Polish with German summary). Szczecińskie Towarzystwo Naukowe, Wydział Nauk Przyrodniczo-Rolniczych, Szczecin.

Johansson M.B. 1995. The chemical composition of needle and leaf litter from Scots pine, Norway spruce and white birch in Scandinavian forests. Forestry, 68, 49-62.

Joosten H., Clarke D. 2002. Wise use of mires and peatlands: background and principles including a framework for decision-making. International Peat Society; International Mire Conservation Group, Saarijärvi, Finland.

Kącki Z., Śliwiński M. 2012. The Polish Vegetation Database: structure, resources and development. Acta Societatis Botanicorum Poloniae, 81, 75-79.

Koczywąs E., Niedźwiedzki P., Pieńkowski M. 2012. Erechtites hieracifolia (L.) Raf. ex DC. invasive alien species in the flora of central Poland (in Polish with English summary). Studia i Materiaty CEPL w Rogowie, 33, 234-240.

Kollmann J.C., Rasmussen K.K. 2012. Succession of a degraded bog in NE Denmark over 164 years - monitoring one of the earliest restoration experiments. Tuexenia, 32, 67-85.

Kozlowski T.T., Pallardy S.G. 1997. Physiology of woody plants. Second Edition. Academic Press, San Diego.

Kujawa-Pawlaczyk J., Pawlaczyk P. 2005. Wetlands conservation (in Polish). In: Nature conservation in forests. II. Conservation of the plant cover (ed.: D.J. Gwiazdowicz), Wydawnictwo Ornatus, Poznań, 105-119.

Laine J., Vasander H., Laiho R. 1995. Long-term effects of water level drawdown on the vegetation of drained pine mires in Southern Finland. Journal of Applied Ecology, 32, 785-802.

Limpens J., Berendse F., Klees H. 2003. N deposition affects $\mathrm{N}$ availability in interstitial water, growth of Sphagnum and invasion of vascular plants in bog vegetation. New Phytologist, 157, 339-347.

Macdonald S.E., Yin F. 1999. Factors influencing size inequality in peatland black spruce and tamarack: evidence from post-drainage release growth. Journal of Ecology, 87, 404-412.

Maciantowicz M., Najbar B., Stańko R., Winiecki A. 1999. Conservation plan for "Mszar Bogdaniec" na- 
ture reserve for time from 1.1.1998 to 31.12.2017 (in Polish). Regionalna Dyrekcja Ochrony Środowiska w Poznaniu. Tapescript.

Oksanen J., Blanchet F.G., Kindt R., Legendre P., Michin P.R., O'Hara R.B., Simpson G.L., Solymos P., Henry M., Stevens H., Wagner H. 2013. vegan: Community Ecology Package. R package version 2.0-10. http://CRAN.R-project.org/package=vegan Accessed 14.11.2015.

Orlov O., Yakushenko D.M. 2011. Distribution and ecocoenological peculiaritities of Erechtites hieracifolia (L.) RAF. ex DC. (Asteraceae) in Ukraine (in Ukrainian with English summary). Ukrainian Botanical Journal, 68, 795-804.

Parish F., Sirin A., Charman D., Joosten H., Minayewa T., Silvus M., Stringer L. 2008. Assessment on peatlands, biodiversity and climate change. Wetlands International, Wageningen.

Ratyńska H., Wojterska M., Brzeg A., Kołacz M. 2011. Multimedia encyclopedia of plant communities of Poland (in Polish). NFOSiGW, UKW, IETI.

R Core Team. 2013. R: A language and environment for statistical computing. R Foundation for Statistical Computing, Vienna, Austria.

Sarkkola S., Alenius V., Hökkä H., Laiho R., Päivänen J., Penttilä T. 2003. Changes in structural inequality in Norway spruce stands on peatland sites after water-level drawdown. Canadian Journal of Forest Research, 33, 222-231.

Sarkkola S., Hökkä H., Koivusalo H., Nieminen M., Ahti E., Päivänen J., Laine J. 2010. Role of tree stand evapotranspiration in maintaining satisfactory drainage conditions in drained peatlands. Canadian Journal of Forest Research, 40, 1485-1496.

Sarkkola S., Hokka H., Penttila T. 2004. Natural development of stand structure in peatland Scots pine following drainage: results based on long-term monitoring of permanent sample plots. Silva Fennica, 38, 405-412.

Schumann M., Joosten H. 2008. Global peatland restoration manual. Institute of Botany and Landscape Ecology, Greifswald University, Germany.

Szaniawski R.K. 1979. Gas exchange and water relations (in Polish with English summary). In: Birches Betula L., Our Forest Trees (ed.: S. Białobok), PWN, Warszawa-Poznań, 105-121.

Talbot J., Richard P.JH., Roulet N.T., Booth R.K. 2010. Assessing long-term hydrological and ecological responses to drainage in a raised bog using paleoecology and a hydrosequence. Journal of Vegetation Science, 21, 143-156.

Tokarska-Guzik B., Górski P., Czarna A. 2009. Erechtites hieraciifolia (in Polish). In: Invasive plant species of wetland ecosystems of Poland (eds.: Z. Dajdok, Z. Kącki), Wydawnictwo Klubu Przyrodników, Świebodzin, 36-37.

Tomassen H., Smolders A.J., Limpens J., Lamers L.P., Roelofs J.G. 2004. Expansion of invasive species on ombrotrophic bogs: desiccation or high $\mathrm{N}$ deposition? Journal of Applied Ecology, 41, 139-150.

Woziwoda B., Kopeć D. 2014. Afforestation or natural succession? Looking for the best way to manage abandoned cut-over peatlands for biodiversity conservation. Ecological Engineering, 63, 143-152.

Zarządzenie Ministra Ochrony Środowiska z dnia 11 grudnia 1995 w sprawie uznania za rezerwat przyrody (in Polish). 1996. Monitor Polski, 5, 49.

Zarzycki K. 1979. Outline of ecology (in Polish with English summary). In: Birches Betula L., Our Forest Trees (ed.: S. Białobok), PWN, WarszawaPoznań, 265-291.

Żurek S. 2006. Catalogue of nature reserves on the Polish peatlands (in Polish). Wydawnictwo Akademii Świętokrzyskiej, Kielce. 